\title{
2007 Farm Bill Survey: Characteristics of Southern Producers ${ }^{1}$
}

\author{
Rodney L. Clouser, Nathan B. Smith, Michele C. Marra, and James L. Novak ${ }^{2}$
}

\section{Introduction}

The Farm Security and Rural Investment Act of 2002 (also known as the 2002 U.S. Farm Bill) authorizes many federal farm programs through 2007. Before this authorization expires, congressional action is expected on future federal farm programs and development of a new comprehensive Farm Bill. The current congressional focus on budget priorities and spending levels at the national level and the on-going negotiation of international trade agreements will certainly influence debate on the next Farm Bill. During these deliberations for the next Farm Bill, information regarding alternatives and preferences will be an important part of the decision making process. Land grant universities and Extension policy specialists have contributed to past Farm Bill deliberations by providing information on producer preferences. This information has been gathered through surveys of agricultural producers coordinated by state Extension specialists under the support of the National Public Policy Education Committee and the Farm Foundation in coordination with the National Agricultural Statistics Service of the United Stated Department of Agriculture.
Nationally, 27 states participated in a farm/agricultural producer survey concerning attitudes and views regarding U.S. Congressional enactment of the next farm bill. Of the 27 states participating in the survey, five were from the South: Alabama, Florida, Georgia, North Carolina, and Texas.

\section{Farm Survey Questionnaire}

Questionnaires were mailed to over 11,800 southern agricultural producers by random sample during the winter of 2005-06. Approximately 22 percent of the surveys $(2,567)$ were returned by the designated return date. Of the 2,567 surveys returned, 212 were considered unusable (for statistical purposes, the reporting of farm sales was necessary to ensure proportional representation in the national summary). The usable survey response was 20 percent $(2,355$ surveys).

1. This is EDIS document FE686, a publication of the Food and Resource Economics Department, Florida Cooperative Extension Service, Institute of Food and Agricutlural Sciences, University of Florida, Gainesville, FL. Published March 2007. Please visit the EDIS website at http://edis.ifas.ufl.edu.

2. Rodney L. Clouser, Professor, Food and Resource Economics Department, Florida Cooperative Extension Service, Institute of Food and Agricutlural Sciences, University of Florida, Gainesville, FL; Nathan B. Smith, Professor and Specialist, Agricultural and Applied Economics Department, University of Georgia, Tifton, GA; Michele C. Marra, Professor and Specialist, Agricultural and Resource Economics Department, North Carolina State University, Raleigh, NC; and James L. Novak, Professor and Specialist, Agricultural Economics and Rural Sociology Department, Auburn University, Auburn, AL. 


\section{Participant Demographics: Age, Gender, and Race}

Regionally, most southern agricultural producers (respondents) participating in the survey were in the 65 and older age category ( 37 percent). Results for the South are reported in Table 1. Texas (40 percent) had the largest percentage of participants in the 65 and older age category, and Florida (32 percent) had the fewest. Regionally, about 92 percent of all responses were from agricultural producers in the 45 to 54 age category, and 66 percent were from those in the 55 to 64 age category. There were no responses from those in the under 25 age category. The South had a higher percentage of producers in the 65 and older age category than any of the other regions in the country, and two-thirds of southern respondents were 55 years or older (the highest percentage reported among the four regions).

Eighty-eight percent of the respondents were male and 12 percent were female (Table 2). The states with the highest female participation were Florida (16 percent) and Georgia (14 percent). In the South, 3 percent of the respondents chose Spanish, Hispanic, or Latino origin as their racial classification, with Florida (7 percent) having more than double any of the other states (Table 3). Ninety-six percent of the respondents chose white as their racial classification. Almost 2 percent chose black as their racial classification (Table 3 ), with Alabama having the largest percentage (5 percent).

\section{Education}

Over 70 percent of the respondents had either attended a college or technical school (Table 4). Twenty-five percent had graduated with a bachelor's degree and an additional 15 percent had graduated with an advanced degree. On the other end of the scale, only 5 percent had left school before completing high school/GED equivalent. Southern respondents scored the highest for post-secondary education training. In both Florida and Texas, over 40 percent of the respondents had a college degree.

\section{Farm Bill Goals}

Participants were asked to rate the importance for eight Farm Bill goals on a scale where 1=least important, $2=$ less important, $3=$ neutral, $4=$ important, and $5=$ most important. The results are reported in Table 5. The composite ranking for the South indicated that all goals were ranked as important, except for reducing farm risk (3.9). Relative rankings in the South differed slightly from other regions in the country. Responses from the South and West indicated that the most important goal was a safe, secure, and affordable food supply. The North Central ranked reducing dependence on non-renewable energy and the Northeast ranked enhancing small and beginning farm opportunities as the highest ranked goals. Nationally, the top three goals were reducing dependence on non-renewable energy; enhancing small and beginning farm opportunities; and assuring a safe, secure, and affordable food supply.

\section{Farm Sales and Farm Income}

Farm sales were summarized into three categories: sales less than $\$ 100,000$ (small); sales above $\$ 100,000$ but less than $\$ 250,000$ (medium); and sales above $\$ 250,000$ (large). The South had a higher participation from small- and medium-size farms than the national survey average (Table 6). Over two-thirds of the southern respondents had sales less than $\$ 100,000$ compared to the national rate of 57.5 percent. All southern states, except Texas, had over 66 percent of the responses from producers with farm sales less than $\$ 100,000$. Almost 20 percent of the national participants had farm sales greater than $\$ 250,000$, but only about 16 percent of southern respondents were in this sales category. Texas most closely resembled the national survey distribution of farm sales, and Alabama least resembled the national distribution of farm sales, with over 90 percent (compared to 80 percent nationally) of their respondents reporting sales less than $\$ 250,000$.

About 69 percent of the southern respondents indicated that they earned less than 50 percent of their family income from farming or ranching (Table 7). This percentage is higher than that of any other region in the country, meaning that only about one of 
every three southern respondents earned over 50 percent of the family income from farming or ranching.

\section{Past Participation in Government Programs}

Participants in the survey were asked to indicate which government programs they had participated in recently. Southern respondents regionally had the second highest participation rate in federal farm programs (63 percent), trailing only the North Central (86 percent). The most common program participation was in farm support programs such as commodity, insurance, credit, and disaster programs (Table 8). A smaller percentage of respondents in the region participate in conservation programs such as working lands, land retirement, or land preservation programs.

\section{Land Ownership and Future Use}

Over 60 percent of the southern respondents own between 75 and 100 percent of the land that is part of their farm operations. Three-quarters of the Florida and Georgia respondents own at least 75 percent of the land they farm while only 58 percent of the Texas respondents own a similar amount of land (Table 9). When asked about what might happen to their farms or ranches when they were no longer operating them, the answer varied considerably among the southern states. Almost 45 percent of Florida respondents indicated that they expected their farms to be converted to non-farm use as opposed to only 14 percent of Texas respondents (Table 10). Responses indicated that about 22 percent of current farms in the South would be converted to non-farm uses, which is comparable to responses from the West (23 percent) and slightly below the Northeast (29 percent).

Forty-four percent of the southern respondents expect their children to operate the farm in the future, which is slightly higher than any other region in the country.

\section{Summary}

Over 2,300 southern agricultural producers participated in the survey on the 2007 Farm Bill. The South had a higher percentage of agricultural producers in the 65 and older and 55 to 64 age categories than any of the other regions in the country (two-thirds of the southern respondents were 55 years or older). Over 70 percent of the southern respondents had attended a college or technical school. The South indicated that the most important goal for the next Farm Bill was a safe, secure, and affordable food supply. Over two-thirds of the southern respondents had sales less than $\$ 100,000$ compared to the national rate of 58 percent. About 69 percent of the southern respondents indicated that they earned less than 50 percent of their family income from farming or ranching. Over 60 percent of the southern respondents own between 75 and 100 percent of the land that is part of their farm operations. Approximately 22 percent of the southern respondents expect that their farms may be converted to non-farm uses in the future.

\section{References}

Clouser, Rodney L., and Steve Ford. 1990. A 1990 Farm Bill Survey: Characteristics of Florida Producers Who Participated. Food and Resource Economics Extension Notes EN 19. Food and Resource Economics Department, University of Florida, Gainesville, FL (April).

Lubben, Bradely D. 2006. National Agricultural, Food and Public Policy Preference Survey Database Documentation. Department of Agricultural Economics. University of Nebraska, Lincoln, NE (May).

Lubben, Bradley D., Nelson L. Bills, James B. Johnson, and James L. Novak. 2006. The 2007 Farm Bill: U.S. Producer Preferences for Agricultural, Food, and Public Policy. Publication Number 2006-01, Farm Foundation, Oak Brook, IL (September). http://www.farmfoundation.org/projects/ documents/ 2007FarmBillProducerSurveyFINAL.pdf. 
Table 1. Age of respondents.

\begin{tabular}{|lrrrrrr|}
\hline \hline & \multicolumn{5}{c|}{ Percent Composite Responses by State/Region } \\
\hline State/Region & Under 25 & $25-34$ & $35-44$ & $45-54$ & $55-64$ & 65 and Over \\
\cline { 2 - 6 } Florida & 0 & 2 & 9 & 19 & 30 & 39 \\
Georgia & 0 & 1 & 11 & 33 & 23 & 32 \\
North Carolina & 0 & 1 & 6 & 26 & 34 & 34 \\
Texas & 1 & 3 & 9 & 28 & 31 & 30 \\
South & 0 & 1 & 8 & 22 & 29 & 40 \\
\hline North Central & 0 & 1 & 8 & 24 & 29 & 37 \\
Northeast & 0 & 3 & 13 & 29 & 27 & 28 \\
West & 0 & 4 & 12 & 27 & 30 & 27 \\
\hline Nationwide & 0 & 3 & 9 & 27 & 30 & 32 \\
\hline Totals may not add to 100 due to rounding. & & 2 & 11 & 27 & 28 \\
\hline \hline
\end{tabular}

Table 2. Gender of respondents.

\begin{tabular}{|lrr|}
\hline \hline & Percent Composite Responses by State/Region & \\
\cline { 2 - 4 } State/Region & Male & Female \\
\hline Alabama & 89 & 11 \\
Georida & 84 & 16 \\
North Carolina & 86 & 14 \\
Texas & 91 & 9 \\
South & 89 & 11 \\
\hline North Central & 88 & 12 \\
Northeast & 91 & 9 \\
West & 87 & 9 \\
\hline Nationwide & 84 & 16 \\
\hline Totals may not add to 100 due to rounding. & 88 & 12 \\
\hline \hline
\end{tabular}


Table 3. Race or ethnicity of respondents.

\begin{tabular}{|c|c|c|c|c|c|c|}
\hline \multirow[b]{2}{*}{ State/Region } & \multicolumn{6}{|c|}{ Percent Composite Responses by State/Region } \\
\hline & White & $\begin{array}{l}\text { Black or } \\
\text { African } \\
\text { American }\end{array}$ & $\begin{array}{r}\text { Spanish, } \\
\text { Hispanic or } \\
\text { Latino }\end{array}$ & $\begin{array}{r}\text { American } \\
\text { Indian or } \\
\text { Alaska } \\
\text { Native }\end{array}$ & $\begin{array}{r}\text { Native } \\
\text { Hawaiian or } \\
\text { Other Pacific } \\
\text { Islander }\end{array}$ & Asian \\
\hline Alabama & 93 & 5 & 0 & 1 & 0 & 0 \\
\hline Florida & 93 & 3 & 7 & 2 & 1 & 1 \\
\hline Georgia & 95 & 4 & 1 & 1 & 0 & 0 \\
\hline North Carolina & 97 & 2 & 1 & 1 & 0 & 0 \\
\hline Texas & 98 & 2 & 3 & 1 & 0 & 0 \\
\hline South & 96 & 2 & 3 & 1 & 0 & 0 \\
\hline North Central & 99 & 0 & 1 & $\overline{1}$ & 0 & $\overline{0}$ \\
\hline Northeast & 99 & 1 & 1 & 0 & 0 & 0 \\
\hline West & 98 & 0 & 2 & 1 & 0 & 0 \\
\hline Nationwide & 98 & 1 & 2 & 1 & 0 & 0 \\
\hline
\end{tabular}

Table 4. Education of respondents.

\begin{tabular}{|c|c|c|c|c|c|c|}
\hline \multirow[b]{2}{*}{ State/Region } & \multicolumn{6}{|c|}{ Percent Composite Respondes by State/Region } \\
\hline & $\begin{array}{l}\text { Grade } \\
\text { School }\end{array}$ & $\begin{array}{r}\text { Some High } \\
\text { School }\end{array}$ & $\begin{array}{r}\text { High School / } \\
\text { GED }\end{array}$ & $\begin{array}{r}\text { Some College / } \\
\text { Technical } \\
\text { School }\end{array}$ & $\begin{array}{r}\text { College } \\
\text { Bachelor's } \\
\text { Degree }\end{array}$ & $\begin{array}{r}\text { College } \\
\text { Advanced } \\
\text { Degree }\end{array}$ \\
\hline Alabama & 1 & 6 & 22 & 35 & 25 & 11 \\
\hline Florida & 1 & 2 & 19 & 37 & 27 & 15 \\
\hline Georgia & 2 & 5 & 28 & 27 & 20 & 18 \\
\hline North Carolina & 3 & 4 & 26 & 33 & 22 & 12 \\
\hline Texas & 1 & 3 & 24 & 31 & 27 & 15 \\
\hline South & 1 & 4 & 24 & 32 & 25 & 15 \\
\hline North Central & 3 & 4 & 36 & 32 & 19 & 8 \\
\hline Northeast & 5 & 7 & 35 & 23 & 19 & 12 \\
\hline West & 1 & 4 & 20 & 37 & 25 & 13 \\
\hline Nationwide & 2 & 5 & 30 & 32 & 21 & 11 \\
\hline
\end{tabular}


Table 5. Goals for the farm bill.

\begin{tabular}{|c|c|c|c|c|c|c|c|c|}
\hline \multirow[b]{2}{*}{ State/Region } & \multicolumn{8}{|c|}{ Average Scores by State/Region* } \\
\hline & $\begin{array}{c}\text { Enhance } \\
\text { Farm } \\
\text { Income }\end{array}$ & $\begin{array}{c}\text { Reduce } \\
\text { Risk }\end{array}$ & $\begin{array}{l}\text { Increase } \\
\text { Competi- } \\
\text { tiveness }\end{array}$ & $\begin{array}{l}\text { Enhance } \\
\text { Small / } \\
\text { Beginning } \\
\text { Farm } \\
\text { Opport. }\end{array}$ & $\begin{array}{c}\text { Protect } \\
\text { Natural } \\
\text { Res. }\end{array}$ & $\begin{array}{c}\text { Enhance } \\
\text { Rural } \\
\text { Econ. }\end{array}$ & $\begin{array}{c}\text { Assure } \\
\text { Food } \\
\text { Supply }\end{array}$ & $\begin{array}{c}\text { Reduce } \\
\text { Depend. on } \\
\text { Non- } \\
\text { Renewable } \\
\text { Energy }\end{array}$ \\
\hline Alabama & 4.26 & 4.00 & 4.42 & 4.33 & 4.29 & 4.17 & 4.58 & 4.42 \\
\hline Florida & 3.83 & 3.51 & 4.12 & 4.37 & 3.97 & 3.75 & 4.45 & 4.19 \\
\hline Georgia & 3.98 & 3.82 & 4.19 & 4.37 & 4.16 & 4.11 & 4.54 & 4.45 \\
\hline North Carolina & 4.31 & 3.89 & 4.23 & 4.36 & 4.05 & 3.99 & 4.44 & 4.40 \\
\hline Texas & 4.23 & 4.01 & 4.32 & 4.32 & 4.03 & 4.12 & 4.50 & 4.37 \\
\hline South & 4.18 & 3.92 & 4.28 & 4.34 & 4.07 & 4.07 & 4.50 & 4.37 \\
\hline North Central & 4.04 & 3.87 & 4.17 & 4.32 & 3.96 & 4.03 & 4.16 & 4.35 \\
\hline Northeast & 4.15 & 3.71 & 4.01 & 4.34 & 4.07 & 3.95 & 4.23 & 4.27 \\
\hline West & 3.98 & 3.68 & 4.16 & 4.27 & 3.81 & 4.00 & 4.30 & 4.16 \\
\hline Nationwide & 4.08 & 3.85 & 4.19 & 4.32 & 3.98 & 4.03 & 4.29 & 4.32 \\
\hline
\end{tabular}

Table 6. Farm sales of Southern respondents by state/region.

\begin{tabular}{|c|c|c|c|}
\hline & Small $(<\$ 100,000)$ & Medium $(<\$ 250,000)$ & Large $(\$ 50,000)$ \\
\hline State/Region & Number / Percent & Number / Percent & Number / Percent \\
\hline \multirow[t]{2}{*}{ Alabama } & 217 & 21 & 23 \\
\hline & $83.1 \%$ & $8.0 \%$ & $8.8 \%$ \\
\hline \multirow[t]{2}{*}{ Florida } & 181 & 29 & 34 \\
\hline & $74.2 \%$ & $11.9 \%$ & $13.9 \%$ \\
\hline \multirow[t]{2}{*}{ Georgia } & 183 & 18 & 44 \\
\hline & $74.7 \%$ & $7.3 \%$ & $18 \%$ \\
\hline \multirow[t]{2}{*}{ North Carolina } & 431 & 117 & 97 \\
\hline & $66.8 \%$ & $18.1 \%$ & $15.0 \%$ \\
\hline \multirow[t]{2}{*}{ Texas } & 551 & 215 & 181 \\
\hline & $58.2 \%$ & $22.7 \%$ & $19.1 \%$ \\
\hline \multirow[t]{2}{*}{ South } & 1563 & 400 & 379 \\
\hline & $66.7 \%$ & $17.1 \%$ & $16.2 \%$ \\
\hline \multirow[t]{2}{*}{ Nationwide } & 8904 & 3510 & 3079 \\
\hline & $57.5 \%$ & $22.6 \%$ & $19.9 \%$ \\
\hline
\end{tabular}


Table 7. Share of family income from farming or ranching.

\begin{tabular}{|c|c|c|c|c|c|}
\hline \multirow[b]{2}{*}{ State/Region } & \multicolumn{5}{|c|}{ Percent Composite Responses by State/Region } \\
\hline & None & $1-25 \%$ & $26-50 \%$ & $51-75 \%$ & $76-100 \%$ \\
\hline Alabama & 15 & 54 & 11 & 5 & 15 \\
\hline Florida & 12 & 51 & 13 & 10 & 13 \\
\hline Georgia & 15 & 58 & 9 & 5 & 13 \\
\hline North Carolina & 9 & 40 & 13 & 12 & 26 \\
\hline Texas & 7 & 40 & 18 & 11 & 23 \\
\hline South & 9 & 45 & 15 & 10 & 20 \\
\hline North Central & 4 & 31 & 18 & 14 & 32 \\
\hline Northeast & 10 & 43 & 12 & 9 & 25 \\
\hline West & 9 & 39 & 14 & 11 & 28 \\
\hline Nationwide & 7 & 37 & 16 & 12 & 27 \\
\hline
\end{tabular}

Table 8. Federal farm program participation.

\begin{tabular}{lll|}
\hline \hline & Percent Responding "Yes" by State/Region Combined Program Category \\
\cline { 2 - 3 } State/Region & Farm Support Programs & Conservation Programs \\
\hline Alabama & 48 & 44 \\
Florida & 46 & 17 \\
Georgia & 43 & 33 \\
North Carolina & 48 & 20 \\
Texas & 56 & 25 \\
South & 52 & 26 \\
\hline North Central & 77 & 40 \\
Northeast & 41 & 21 \\
West & 47 & 29 \\
\hline Nationwide & 62 & 32 \\
\hline Totals do not add across categories. & & 29 \\
\hline \hline
\end{tabular}


Table 9. Farm or ranch tenure.

\begin{tabular}{|c|c|c|c|c|c|}
\hline \multirow[b]{2}{*}{ State/Region } & \multicolumn{5}{|c|}{ Percent Composite Responses by State/Region } \\
\hline & None & $1-25 \%$ & $26-50 \%$ & $51-75$ & $76-100 \%$ \\
\hline Alabama & 4 & 10 & 10 & 4 & 72 \\
\hline Florida & 10 & 7 & 6 & 3 & 75 \\
\hline Georgia & 3 & 6 & 9 & 7 & 75 \\
\hline North Carolina & 7 & 13 & 10 & 9 & 61 \\
\hline Texas & 7 & 14 & 11 & 10 & 58 \\
\hline South & 6 & 12 & 10 & 8 & 63 \\
\hline North Central & 6 & 4 & 1 & 1 & 56 \\
\hline Northeast & 6 & 7 & 7 & 9 & 72 \\
\hline West & 7 & 8 & 8 & 9 & 68 \\
\hline Nationwide & 7 & 12 & 11 & 10 & 61 \\
\hline
\end{tabular}

Table 10. Expected farm or ranch transition.

\begin{tabular}{|c|c|c|c|c|c|c|}
\hline \multirow[b]{2}{*}{ State/Region } & \multicolumn{6}{|c|}{ Percent Composite Responses by State/Region } \\
\hline & $\begin{array}{r}\text { Operated by } \\
\text { Spouse }\end{array}$ & $\begin{array}{r}\text { Operated by } \\
\text { Children }\end{array}$ & $\begin{array}{l}\text { Operated } \\
\text { by Other } \\
\text { Relatives }\end{array}$ & $\begin{array}{c}\text { Operated by } \\
\text { Non-Relatives } \\
\text { in Current } \\
\text { Operation }\end{array}$ & $\begin{array}{r}\text { Operated by } \\
\text { Individuals } \\
\text { Outside } \\
\text { Current } \\
\text { Operation }\end{array}$ & $\begin{array}{r}\text { Converted to } \\
\text { Non-Farm } \\
\text { Use }\end{array}$ \\
\hline Alabama & 8 & 51 & 4 & 2 & 11 & 23 \\
\hline Florida & 6 & 32 & 5 & 3 & 9 & 45 \\
\hline Georgia & 10 & 38 & 6 & 1 & 11 & 33 \\
\hline North Carolina & 8 & 40 & 7 & 4 & 13 & 27 \\
\hline Texas & 9 & 47 & 7 & 4 & 20 & 14 \\
\hline South & 9 & 44 & 6 & 3 & 16 & 22 \\
\hline North Central & 5 & 43 & 8 & 4 & 27 & 12 \\
\hline Northeast & 4 & 41 & 5 & 3 & 18 & 29 \\
\hline West & 6 & 38 & 6 & 3 & 24 & 23 \\
\hline Nationwide & 6 & 43 & 7 & 3 & 22 & 18 \\
\hline
\end{tabular}

